\title{
Biochemical and Molecular Studies on Bone Marrow Derived Stromal Stem Cells on Liver Injuries in Rats
}

\author{
Mohammed F. Dowidar ${ }^{1}$, Hussein I. El-Belbasi ${ }^{1}$, Azza G.M. Ayoub ${ }^{2}$, Lila A. Rashed ${ }^{3}$ and Dalia \\ W. Elged ${ }^{2 *}$ \\ ${ }^{1}$ Biochemistry Department, Faculty of Veterinary Medicine, Zagazig University, 44511, Egypt \\ ${ }^{2}$ Animal Health Research Institute, Zagazig Branch, Egypt \\ ${ }^{3}$ Biochemistry Department, Faculty of Medicine, Cairo University, Egypt
}

\begin{abstract}
Liver is a remarkable vital organ, it is responsible for metabolizing the different food elements, filtering and detoxifying poisons in the blood to remove numerous toxic compounds. Liver affections are essentially caused by harmful chemicals (certain anti-infection, paracetamol, carbon tetrachloride, aflatoxins, per oxidized oil and so on.), overabundance utilization of liquor, immune system issue and disease. Up till now, orthotropic liver transplantation is the most powerful treatment of liver infections. Because of the deficiency of donors, high costs, the number of patients who can profit by this methodology is extremely constrained. Recently, cell based treatments have been explored as other option to entire liver transplantation. Thirty rats were separated into three equivalent groups $(\mathrm{n}=10$, each). Group 1: control; Group 2: was infused peritoneally with acetaminophen $(300 \mathrm{mg} / \mathrm{kg})$; Group 3: was injected intra peritoneal with acetaminophen $(300 \mathrm{mg} / \mathrm{kg})$, then injected intra-venous with mesenchymal stromal stem cells (1 million BM-MSCs/kg). Blood samples for estimation of liver functions, and liver samples for detection of homing labeled MSCs with red fluorescent cell linker dye (PKH26), gene expression of matrix metalopeptidase (MMP2), tissue inhibitor metalopeptidase (TIMP) and histopathological examination were collected. The infusion of BM-MSCs enhanced liver capacities test, MMP2 and TIMP. Histopathological examination of liver tissue demonstrated critical antifibrotic impact, improvement in the hepatic structure as compared to the second group. It could be concluded that BM-MSC is effective in treatment of liver damage by upgrading hepatocyte recovery through enhancing the liver stress and inflammatory signaling by improving MMP2 and TIMP, besides it has a significant antifibrotic effect. The MSCs stem cell is an attractive cell source for regenerative medicine.
\end{abstract}

Keywords: Acetaminophen, Bone Marrow, Liver Injury, Mesenchymal Stromal Stem Cell.

\section{Introduction}

Stem cells are single cell population with the ability of self-renewal and differentiation into dissimilar cell lines. They were documented as possible tool for advanced therapeutic plans development. Stem cell therapy is a part of a new medical branch called "Regenerative medicine" [1]. There are two types of stem cells according to the origin, the adult stem cell (ASC) and the embryonic stem cell (ESC). The ASC are used in a number of fields with extreme success, especially in cases of hematological malignancies. In vitro and in vivo studies revealed that ASC from one tissue or organ can differentiate into the cells of other organs [2]. Bone marrow- derived stem cells (hematopoietic or mesenchymal) are types of ASC which have important implications with no need for ethical concern inherent to fetal embryonic tissue [3]. The adherence ability of bone marrow stem cells to a plastic support, resulted in an expanded use and culture of these cells. They differentiate into multiple mesenchymal cell types, as well as cartilage, bone, adipose, fibrous tissues and myelosupportive stroma under appropriate experimental conditions [4]. This has led many investigations to explore the potential of their therapeutic applications [5]. Many scientists believe that ESC might be a future solution to most of the diseases. However, it is under research, because of the ethical barriers related to its usage [6].

It is expected that stem cells will be the basis for what is known as cell based therapy for treating various diseases. Cells- based therapy relies on replacing diseased or dysfunctional cells with healthy functioning

*Corresponding author email: (daliaelged@yahoo.com), Animal Health Research Institute, Zagazig 355 branch, Egypt. 
ones [7]. Scientists primarily studied ESC or ASC of animals and humans.

Embryonic stem cells can be isolated from the embryo at a gestation age of 3-5 days (blastocysts). Their use in research and therapy is limited due to ethical considerations. Adult stem cells can be isolated from various tissues such as muscles, liver, gastrointestinal tract, adipose tissue and bone marrow [8].

The ASC has two types of stem cells; the hematopoietic stem cells (HSCs) and the mesenchymal (non- hematopoietic) stem cells (MSCs). Bone marrow mesenchymal stem cells are also referred to as marrow stromal cells [9], colony creating unit fibroblast and marrow stromal stem cells [10], and as multipotential mesenchymal progenitor cells (MPCs) [11].

The HSCs give rise to all circulating blood cells, while MSCs can be induced to differentiate into different mesenchymal linages such as osteoblastic, chondroblastic and adipocytic lineages, when cultured into appropriate environments, in vitro [9]. The bone marrow represents the first source of MSCs, because they can be easily obtained after aspiration from the sternum or the iliac crest of the human volunteer donors after informed consent [12].

Applications of stem cells include many fields of medicine such as cardiology, neurology, hematology, hepatology, immunological diseases, and diabetes mellitus and as a cell model for drug trials [13]. MSCs distinguish into osteoblasts, adipocytes, chondrocytes [14], monocytes [15], astrocytes, oligodendrocytes, neurons [16] and hepatocytes [17]. Consequently, the cells are tested for their use in cell and gene therapy for a number of diseases [18]. The ability of MSCs to distinguish into hepatocytes in vitro [17] also in vivo has been recently reported [19]. Moreover, injuries, lung, liver or heart can be repaired by MSCs administration [19].

In the field of hepatology, stem cells differentiated into hepatocytes introduce new functioning liver cells into diseased organs, supporting intrinsic liver regeneration. New clinical studies also showed that hepatocyte transplantation may be effective in treating children with liver-based metabolic diseases
[20]. The purpose of the current study was to evaluate the protective and therapeutic effects of MSCs in injured- liver rats induced by acetaminophen.

\section{Materials and Methods}

Isolation of MSCs from femur and tibias of rats and cultivation of MSCs in Dulbecco modified Eagle medium supplemented with $10 \%$ fetal bovine medium was performed. MSCs in culture were characterized by their adhesiveness and fusiform spindle shape [21], and then they were identified by flow cytometer. Briefly, MSCs were washed and suspended in phosphate-buffer saline, CD45 and CD90 monoclonal antibodies (vendor) were added to cells and kept for $1 \mathrm{~h}$ at $4^{\circ} \mathrm{C}$, incubated with anti-mouse immunoglobulin $\mathrm{G}$ for (vendor) $45 \mathrm{~min}$ on ice, then analyzed on FACS caliber flow cytometer. After that, we labeled the isolated MSCs with PKH26 red fluorescent dye (Sigma Aldrich) and injected them in rat tail vein for indicating homing of MSCs in rat liver. Thirty rats of 130-170 gm body weight were divided into three equal groups. Group 1: control; Group 2: were injected I/P with acetaminophen $(300 \mathrm{mg} / \mathrm{kg}$ BW); Group 3: were injected $\mathrm{I} / \mathrm{P}$ with acetaminophen $(300 \mathrm{mg} / \mathrm{kg} \mathrm{BW})$, then injected with mesenchymal stromal stem cells I/V [22]. After 2 weeks from injection of stem cells, the animals were fasted overnight. Blood samples were collected from the retro-orbital venous plexus for assessment of liver functions (ALT, AST, ALP, total protein, albumin, direct bilirubin and indirect bilirubin) and liver samples were also collected for the detection of MSCs homing after its labeling with red fluorescent cell linker dye (PKH26) dye by inverted microscope, for histopathological examination, and for gene expression of matrix metalopeptidase (MMP2), tissue inhibitor metalopeptidase (TIMP) [23].

\section{Results and Discussion}

Liver is a remarkable vital organ in both form and function. It is responsible for preforming more functions than any other organ in the body. Liver illnesses are mainly initiated by toxic chemicals (certain antibiotics such as amoxicillin in a large dose, aflatoxin, carbon tetrachloride, paracetamol in a large dose, chlorinated hydrochloride, etc.), excessive alcohol, infections and autoimmune 
disorders [24]. Some chemicals or viral infections often lead to liver fibrosis, which subsequently causes an impairment of liver function that required medical intervention [25]. Acetaminophen was originally used as an analgesic in therapeutic dose, however, at higher doses; it causes fatal hepatic necrosis $[26,27]$. Injury to the liver is not due to the drug itself, but due to a toxic metabolite $(\mathrm{N}$ - acetyl-p-benzoquinone imine (NAPQI) created by cytochrome P-450 enzymes in the liver [28]. Normally, detoxification of this metabolite occurs by conjugation with glutathione. In overdose, a large amount of NAPQI is generated impairing the process of detoxification and then results in liver cell injury. In addition, Nitric oxide has a role in inducing toxicity [29].

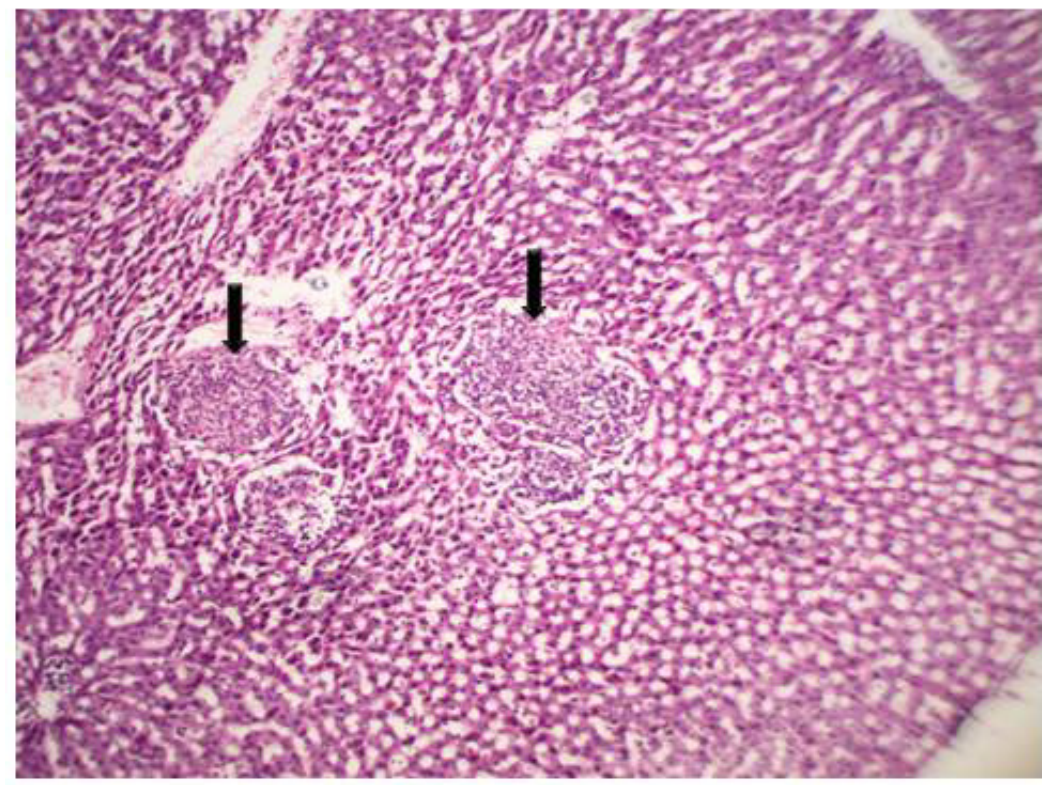

Figure 1: Liver of rat (acetaminophen) showing multiple focal areas of coagulative necrosis (arrows) $\mathrm{H \& E}$ (X100).

In this study, when rats were injected with acetaminophen (300 $\mathrm{mg} / \mathrm{kg} \quad \mathrm{BW})$ intra peritoneal [30], the liver showed multiple focal areas of coagulative necrosis of variable sizes infiltrated by mononuclear cells; some portal areas contain numerous bile ductules and fibrous tissue infiltrated with few lymphocytes and hyalinization in portal vein (Figure 1). This result is in agreement with Davidson and Eastham [31]. Hepatotoxicity of acetaminophen was reported in rodents treated with overdose in different studies [32,33]. Acute liver failure (ALF) causes both high morbidity and mortality rates (> 80\%). Liver transplantation is the only viable approach to the treatment of ALF. This has significantly improved the survival in patients [34]. However, the major limitations of liver transplantation are non-availability of the donor liver, major surgical approach, high cost and long-term immunosuppression [35]. Cell therapy by transplantation of hepatocytes or bone marrow cells is also attractive approach by stimulation of endogenous or exogenous regeneration by stem cells [36]. In the present study, BM-derived MSCs were isolated from adult rats and they were characterized in culture by their adhesiveness and fusiform shape (Figure 2). This was consistent with another study [36]. The possible therapeutic advantage of MSCs can only be understood through their homing proficiency to the obligatory site. The homing of MSCs in this study was noticed by PKH26 dye which was used to label MSCs $[37,38]$. 


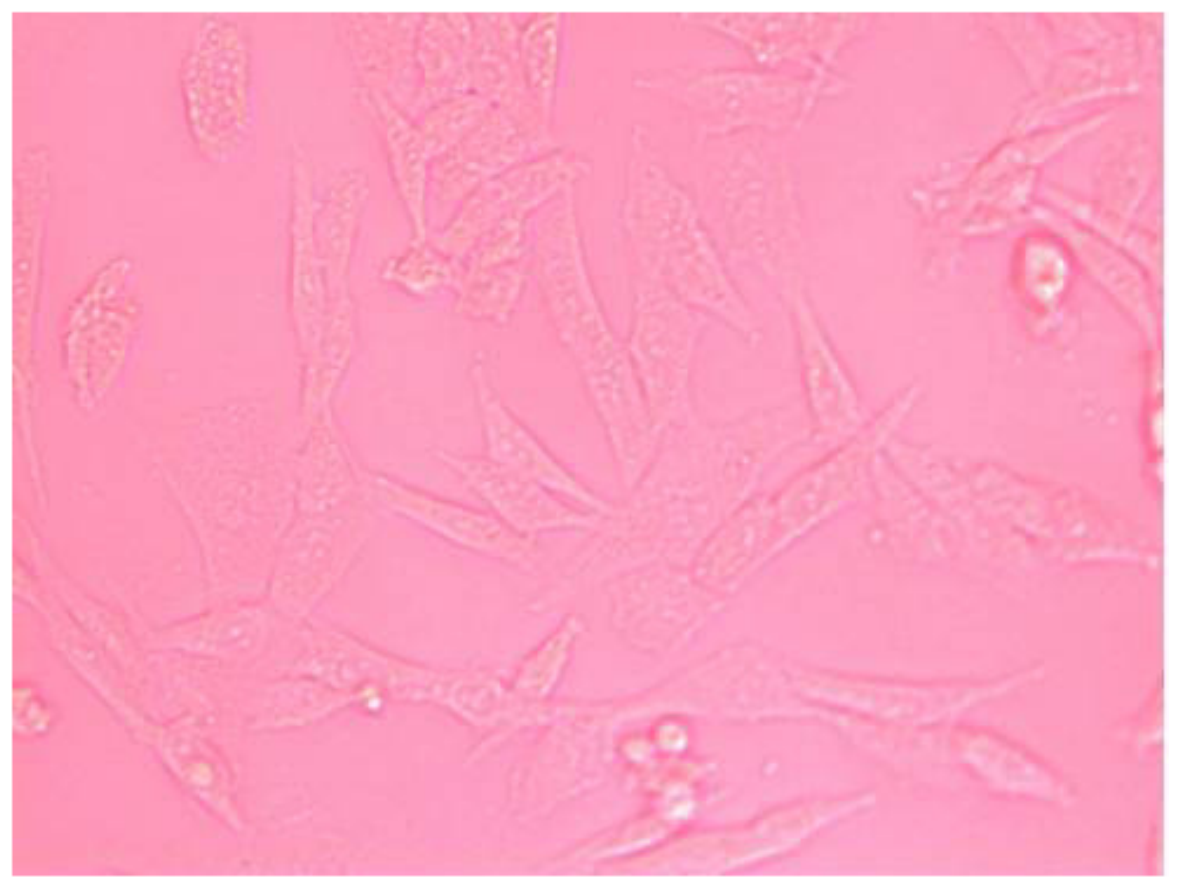

Figure 2: Dulbecco's modified Eagle's (DMEM) culture media change of 10 days age showing bone-marrow mesenchymal stem cells (BM-MSCs) of rat appeared as spindle shape cells using inverted microscope.

Munoz et al. [39] labeled bone marrow MSCs with PKH26 dye and engaged it as red fluorescence of MSCs. Identification of MSCs of antibody markers using molecular detection of the expression of the specific markers CD45 (leukocyte marker) and CD90 (mesenchymal marker) by RT-PCR was carried out (Figure $3)$. The results showed that MSCs were positive for CD90, and negative for CD45; these results indicated that relatively purified bone marrow- derived MSCs were isolated. This was in agreement with many investigators who isolated MSCs from bone marrow and characterized it by different combination of CD markers. Wu et al. [40] found that BMMSCs were typical of spindle and fibrocysticlike adherent monolayers with high CD90, CD29 positive rate and very low CD45 expression.

This study assessed the protective effects of infusion BM-derived MSCs to rats on the advancement of liver injuries using the experimental model of acetaminophen induced liver injuries in rats. 
Table 1: The activities of some liver enzymes and MMP2, TIMP mRNA expression after two weeks of MSCs administration (mean values $\pm \mathrm{SE}$ )

\begin{tabular}{lccc}
\hline Enzyme & $\begin{array}{c}\text { Group 1 } \\
\text { (Control) }\end{array}$ & $\begin{array}{c}\text { Group 2 } \\
\text { (acetaminophen) }\end{array}$ & $\begin{array}{c}\text { Group 3 } \\
\text { (Acetaminophen+ MSCs) }\end{array}$ \\
\hline ALT & $18.36 \pm 1.952^{\mathrm{b}}$ & $62.00 \pm 8.515^{\mathrm{a}}$ & $32.00 \pm 3.010^{\mathrm{b}}$ \\
AST & $14.80 \pm 1.908^{\mathrm{c}}$ & $71.80 \pm 5.928^{\mathrm{a}}$ & $38.75 \pm 3.250^{\mathrm{b}}$ \\
ALP & $124.7 \pm 4.024^{\mathrm{b}}$ & $372.9 \pm 18.559^{\mathrm{a}}$ & $187.8 \pm 9.966^{\mathrm{b}}$ \\
Total proteins & $8.120 \pm 0.317^{\mathrm{a}}$ & $4.682 \pm 0.401^{\mathrm{c}}$ & $7.266+{ }^{\mathrm{b}} 0.333^{\mathrm{b}}$ \\
Albumin & $4.968 \pm 0.284^{\mathrm{a}}$ & $2.542 \pm 0.222^{\mathrm{c}}$ & $3.920 \pm 0.225^{\mathrm{b}}$ \\
Direct bilirubin & $0.280 \pm 0.025^{\mathrm{b}}$ & $0.556 \pm 0.0635^{\mathrm{a}}$ & $0.310 \pm 0.015^{\mathrm{b}}$ \\
Indirect bilirubin & $0.722 \pm 0.054^{\mathrm{b}}$ & $1.362 \pm 0.1684^{\mathrm{a}}$ & $0.862 \pm 0.054^{\mathrm{b}}$ \\
MMP 2 & $1.006 \pm 0.014^{\mathrm{c}}$ & $11.88 \pm 0.800^{\mathrm{a}}$ & $3.805 \pm 0.946^{\mathrm{b}}$ \\
TIMP & $1.050 \pm 0.072^{\mathrm{a}}$ & $0.276 \pm 0.048^{\mathrm{c}}$ & $0.788 \pm 0.107^{\mathrm{b}}$ \\
\hline
\end{tabular}

Mean carrying different super scripts within the same raw are significantly different at $\mathrm{P}<0.05$, based on Duncan's multiple comparisons and the highest value is letter (a). MMP2: matrix metalopeptidase, TIMP: tissue inhibitor metallopeptidase.

In this work, liver functions (serum ALT, AST, ALP, total proteins, albumin, total bilirubin, direct bilirubin and indirect bilirubin) were investigated in all groups (Table 1). Serum protein and albumin were decreased, while ALT, AST, ALP, bilirubin levels were increased in the injured groups. These results were in agreement with Roberts et al. [41] and $\mathrm{Hu}$ and Colletti [42] who reported significant increases in serum AST, ALT in mice after administration of acetaminophen. Prescott and Critchley [43] summarized the biochemical changes after an acetaminophen overdose to be a dramatic rise in serum ALT and AST activities, mild hyper bilirubinemia and raised prothrombin time [44].

In the present study, when rats were injected by MSCs next to injection of acetaminophen, the liver functions were enhanced. The total serum proteins and albumin levels were increased in the group of rats which received MSCs, while ALT, AST, ALP, direct and indirect bilirubin were decreased (Table 1). These findings were consistent with the results reported by ElKhayat et al. [45] who showed that MSCs management have significant enhancement in liver functions of the treated group compared to the fiber-optic group. Jang et al. [46] found that liver function of mice received the mesenchymal stromal stem cells were recovered as early as two days after transplantation of MSCs.

Transplantation of bone marrow stromal stem cells enhances the ability of hepatocytes in vivo and in vitro as they enhance the viability and phenotypes (maintenance of hepatocytes) where the BMSc act as feeders for the liver cells [47]. Also, transplantation of bone marrow mesenchymal stromal stem cells can distinguish into hepatocytes, reestablish the plasma albumin level, and overwhelm transaminase activity and liver fibrosis in trial model of liver injury [38,48]. The improvements of liver function are explained by the fact that the MSCs lower the fibrosis and allow the repopulation of the liver with normal hepatocytes [49].

This study showed that transplantation of mesenchymal stromal stem cells decreased AST, ALT and prothrombin time to level observed in control rats (Table 1). This was comparable with other studies [30, 49-50].

The degree of fibrosis was monitored in the liver tissue by detection of MMP2 and TIMP (fibrous gene expression). MSCs have important antifibrotic influence as indicated by the decrease in MMP2 and increases TIMP (Table 1). 


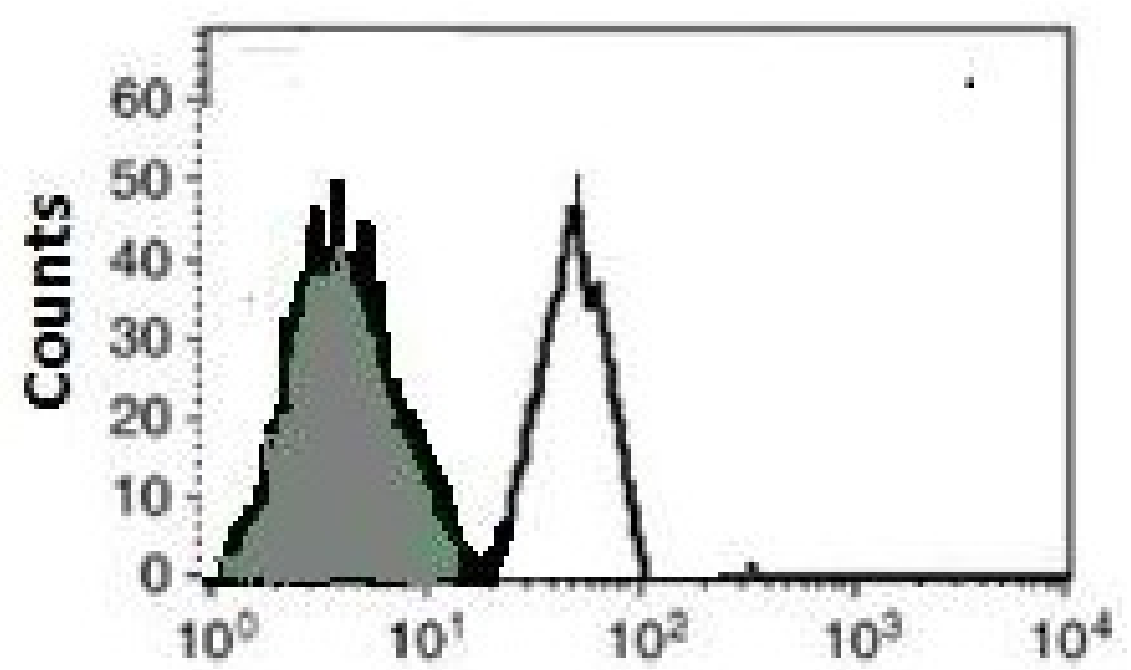

Figure 3: Flow Cytometer analysis of BM-MSC s surface markers Cells were positive to CD90.

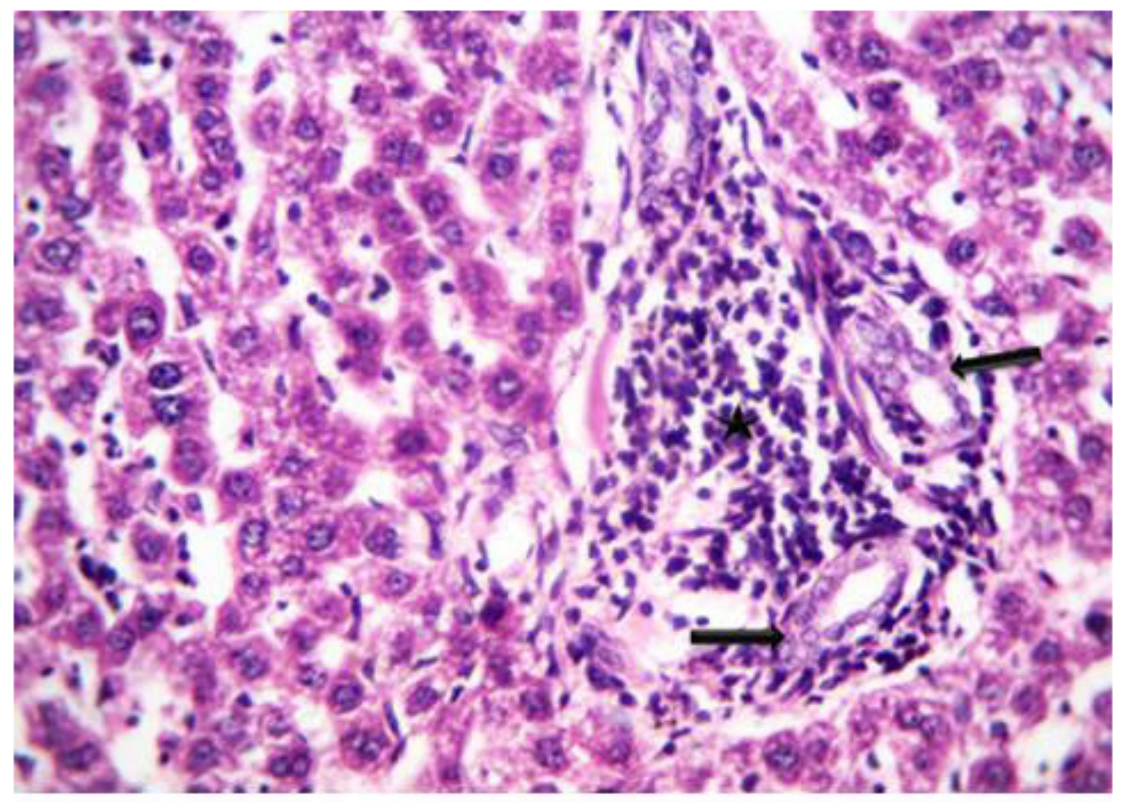

Figure 4: Liver of treated rat (Acetaminophen+MSCs) showing portal area infiltrated by lymphocytes (star) and numerous bile ductules (arrows) beside normal hepatic cords. H\&E (X400).

Matrix-degrading metalloproteinase enzyme and specific matrix degrading metalloproteinase inhibition [51,52] may reveal that the distillation of $\mathrm{BM}$ derived MSCs may have a protective influence in contradiction of liver fibrosis. This is in agreement with the result reported by Salomon et al. [30] who showed that mesenchymal stromal stem cell transplantation is effective in treating acetaminophen liver injury by enhancing hepatocyte regeneration and inhibiting liver stress and inflammatory signaling. The accumulation of ECM proteins interferes with the hepatic architecture by creating fibrous scar. Accretion of ECM is originated from both increased synthesis and decreased degradation [53]. The reduction in ECN activity removing factors, e.g. Matrix Metalloproteinase (MMP) are mainly due to over expression of their specific inhibitor such as tissue inhibitor of metalloproteinase (TIMP). 
Liver pathology serves as an important tool for identifying and characterizing liver injury. The main pattern of liver injury through hepatotoxicity may contain zonal necrosis, hepatitis, cholestasis, granuloma, steatosis, vascular lesion [54]. In this study, samples were taken from the liver of rats of different groups. Histological examination of liver tissue of the control group indicated normal hepatic parenchyma, while in the acetaminophen group, liver showed multiple focal area of coagulated necrosis infiltrated by mononuclear cells scattered in the hepatic parenchyma, as reported by Chandrasekaran $e t$ al. [55]. Other hepatic cells suffered from different types of cell injuries or accumulation mainly microsteatosis with dilated hepatic sinusoids and pressure atrophy of cords compared with the control group. Some portal areas showed fibrous tissue infiltrated by lymphocytes and hyalinization of the portal vein. While, liver investigation of the treated group with $\mathrm{BM}$ mesenchymal stromal stem cells showed improvement in the hepatic structure compared with the control group which had normal hepatic cord and few portal areas of fibrous tissue infiltrated with lymphocytes, as shown in Figure (4). These results were comparable with Ries et al. [56] who found that BM MSCs has a significant antifibrotic effect. Also, liver section of intoxicated rat with acetaminophen showed lobular necrosis and diffuse vascular degeneration, whereas, in rat transplanted with mesenchymal stromal stem cells, liver injury was almost absent. Stock et al. [57] showed that MSCs reduced the inflammatory response and support liver regeneration following acute liver injury induced by acetaminophen. Therefore, MSCs may serve as a novel source of the hepatocytes and are suitable for the cell therapy of acute liver diseases.

\section{Conclusion}

From the current study, it could be concluded that transplantation of BM-MSCs is effective in treating acetaminophen liver injury by enhancing hepatocyte regeneration, inhibiting liver stress and inflammatory signaling by improving matrix metalopeptidase (MMP2) and tissue inhibitor metalopeptidase (TIMP). The MSCs stem cells is an attractive cell source for regenerative medicine. Further studies are needed to apply the effect of stem cells in liver disease.

\section{Conflict of interest}

The authors declare no conflict of interest.

\section{References}

[1] Sell, S. (2004): Heterogenicity and plasticity of hepatocyte lineage cells. Hepatology, 33(3): 738-757.

[2] Anderson, D.J; Gage, F.H; and Weissman, I.L. (2001): Can stem cells cross lineage boundaries?. Nat Med, 7 (4): 393-395.

[3] Krause, D.S.; Theise, N.D.; Collector, M.I.; Henegariu, O.; Hwang, S.; Gardner, R. and Sharkis, S.J. (2001): Multi-organ, multi-lineage engraftment by a single bone marrow-derived stem cell. Cell, 105 (3): 369-377.

[4] Deans, R.J. and Moseley, A.B. (2000): Mesenchymal stem cells: biology and potential clinical uses. Exp Hematol, 28 (8): 875-884.

[5] Gabr, M.M.; Sobh, M.M.; Zakaria, M.M.; Refaie, A.F. and Ghoneim, M.A. (2008): Transplantation of insulin-producing clusters derived from adult bone marrow stem cells to treat diabetes in rats. Exp Clin Transplant, 6 (3): 236-243.

[6] Taupin, P. (2006): The therapeutic potential of adult neural stem cells. Curr Opin Mol Ther; 8(3):225-31.

[7] Jackson, K.A.; Majka, S.M.; Wang, H., Pocius, J.; Hartley, C.J.; Majesky, M.W.; Entman, M.L.; Michael, L.H.; Hirschi K.K. and Goodell, M,A. (2001): Regeneration of ischemic cardiac muscle and vascular endothelium by adult stem cells. J Clin Invest, 107 (11): 1395-402

[8] Jiang, Y.; Jahagirdar, B.N.; Reinhardt, R,L.; Schwartz, R.E.; Keene, C.D., OrtizGonzalez, X.R.; Reyes, M,; Lenvik, T; Lund; T, Blackstad, M; Du. J; Aldrich, S; Lisberg, A; Low, W.C.; Largaespada, D.A. and Verfaillie, C. (2002): Pluripotency of mesenchymal stem cells derived from adult marrow. Nature, 418 (6893): 41-49.

[9] Pittenger, M.F.; Mackay, A.M.; Beck, S.C.; Jaiswal, R.K.; Douglas, R.; Mosca, J.D.; Moorman, M.A.; Simonetti, D.W.; 
Craig, S. and Marshak, D.R. (1999): Multi-lineage potential of adult human mesenchymal stem cells. Science, 284(5411):143-147.

[10] Bianco, P.; Riminucci, M.; Gronthos, S.; and Robey, P.G. (2001): Bone marrow stromal stem cells: nature, biology, and potential applications. Stem Cells, 19 (3): 180-192.

[11] Jones, E.A.; Kinsey, S.E.; English, A.; Jones, R.A.; Straszynski, L.; Meredith, D.M.; Markham, A.F.; Jack, A.; Emery, P. and McGonagle, D. (2002): Isolation and characterization of bone marrow multipotential mesenchymal progenitor cells. Arthritis Rheum, 46(12): 33493360 .

[12] Tondreau, T.; Lagneaux, L.; Dejeneffe, M.; Delforge, A.; Massy, M.; Mortier, C. and Bron, D. (2004): Isolation of BM mesenchymal stem cells by plastic adhesion or negative selection: phenotype, proliferation kinetics and differentiation potential. Cytotherapy, 6 (4): $372-379$.

[13] Kirschstein, R. and Skirbol, L.R. (2001): Executive Summary, the Embryonic Stem Cells In: Stem Cells: Scientific Progress and Future Research Directions. Terse Winslow, pp. 1-22.

[14]Bruder, S.P.; Jaiswal, N. and Haynesworth, S.E. (1997): Growth kinetics, self-renewal and the osteogenic potential of purified human mesenchymal stem cells during extensive subcultivation and following cryopreservation. J Cell Biochem, 64(2): 278-294.

[15] Wakitani, S.; Saito, T. and Caplan, A.I. (1999): Myogenic cells derived from rat bone marrow mesenchymal stem cells exposed to 5-azacytidine. Muscle Nerve, 18(12):1417-26.

[16] Kopen, G.C; Prockop, D.J; and Phinney, D.G. (1999): Marrow stromal cells migrate throughout forebrain and cerebellum, and they differentiate into astrocytes after injection into neonatal mouse brains. Proc Natl Acad SCI USA, 96(19):10711-10716
[17] Lee, D.S.; Gil, W.H.; Lee, H.H.; Lee, K.W.; Lee, S.K. Kim, S.J.; Choi, S.H.; Heo, J.S.; Hyon, W.S.; Kim, G.S.; Paik, S.W.; Koh, K.C. and Joh, J.W. (2004): Factors affecting graft survival after living donor liver transplantation. Transplant. Proc, 36(8): 2255-2256.

[18] Horwitz, E.M.; Prockop, D.J.; Fitzpatrick, L.A.; Koo, W.W.; Gordon, P.L.; Neel, M.; Sussman, M.; Orchard, P.; Marx, J.C.; Pyeritz, R.E. and Brenner, M.K. (1999): Translatability and therapeutic effects of bone marrow-derived mesenchymal cells in children with osteogenesis imperfect. Nat Med, 5(3): 309-313.

[19] Fang, B; Shi, M; Liao, L.; Yang, S; Liu, Y; and Zhao, R.C. (2004): Systemic infection of FLKI (+) mesenchymal stem cells ameliorates carbon tetrachloride induced liver fibrosis in mice. Transplantation, 78(1): 83-88.

[20] Wang, X.; Willenbring, H.; Akkari, Y.; Torimaru, Y.; Foster, M.; Al-Dhalimy, M.; Lagasse, E.; Finegold, M.; Olson, S. and Grompe, M. (2003): Cell fusion is the principal source of bone marrowderived hepatocytes. Nature, 422(6934):897-901.

[21] Alhadlaq, A. and Mao, J.J. (2004): Mesenchymal stem cells; isolation and therapeutics. Stem Cells Dev, 13 (4): 436-448.

[22] Morigi, M.; Introna, M.; Imberti, B.; Corna, D.; Abbate, M.; Rota, C.; Rottoli, D.; Benigni, A.; Perico, N.; Zoja, C.; Rambaldi, A.; Remuzzi, A. and Remuzzi, G. (2008): Human bone marrow mesenchymal stem cells accelerated recovery of acute renal injury and prolong survival in mice. Stem cells, 26(8): 2075-2082.

[23] Livak, K.J. and Schmittgen, T.D. (2001): Analysis of relative gene expression data using real-time quantitative PCR and the 2(-Delta Delta C(T)) method. Methods, 25(4): 402-408.

[24] Raju, S.B.G.; Battu, R. G. and Srinivas, K. (2012): Antihepatotoxic activity of 
smilax china roots on CCL4 induced hepatic damage in rats. Int $\mathrm{J}$ Pharm Pharm Sci, 4 (1): 494-496.

[25] Friedman, S.L. (2003): Liver fibrosis-from bench to bedside. J Hepatol, 38 (Suppl 1): S38-S53.

[26] Ostapowicz, G.; Fontana, R.J.; Schiødt, F.V.; Larson, A.; Davern, T.J.; Han, S.H. McCashland, T.M.; Shakil, A.O.; Hay, J.E.; Hynan, L.; Crippin, J.S.; Blei, A.T.; Samuel, G.; Reisch, J.; Lee, W.M. and U.S. Acute Liver Failure Study Group. (2002): Results of a prospective study of acute liver failure at 17 tertiary care centers in the United States. Ann Intern Med, 137 (12): 947-54.

[27] Larson, A.M.; Polson, J.; Fontana, R.J.; Davern, T.J.; Lalani, E.; Hynan, L.S.; Reisch, J.S.; Schiødt, F.V.; Ostapowicz, G.; Shakil, A.O.; Lee, W.M. and Acute Liver Failure Study Group (2005): Acetaminophen-induced acute liver failure: results of a United States multicenter, prospective study. Hepatol, 42(6): 1364-1372.

[28] Patel, T.; Roberts, L.R.; Jones, B.A. and Gores, G.J. (1998): Dysregulation of apoptosis as a mechanism of liver disease: an overview. Semin Liver Dis, 18 (2): 105-14.

[29] Blumenthal, L.L.; Lazo, J.S.; Parker, K.; Buxton, I. and Blumenthal, D. (2006): Book Review: Goodman and Gilman's The Pharmacological Basis of Therapeutics: Digital Edition

[30] Salomone, F.; Barbagallo, I.; Puzzo, L.; Piazza, C. and Volti, G. (2013): Efficacy of adipose tissue -mesenchymal stem cell transplantation in rats with acetaminophen liver injury. Stem Cell Res, 11 (3); 1037-44.

[31] Davidson, D.G. and Eastham, W.N. (1966): Acute liver necrosis following overdose of paracetamol. Br Med J., 5512: 497-499.

[32] Boyd, E.M. and Bereczky, G.M. (1966): Liver necrosis from paracetamol. Br $\mathrm{J}$ Pharmacol Chemother, 26(3): 606-614.
[33] Mitchell, J.R.; Jollow, D.J.; Potter, W.Z.; Gillette, J.R. and Brodie, B.B. (1973): Acetaminophen-induced hepatic necrosis. IV. Protective role of glutathione. J Pharmacol Exp Ther, 187(1): 211-217.

[34]-Dove, L. and Brown, R. (2004): The emerging role of gastrointestinal organ transplantation. Clin Fam Pract, 6(3):775-91.

[35] Presajak, P. and Leenansaksiri, W. (2014): Mesenchymal stem cells; current clinical applications and therapeutic potential in liver diseases. $\mathrm{J}$ Bone Marrow Res, 2 (1): 2329-8820.

[36] Rochefort, G.Y.; Vaudin, P.; Bonnet, N.; Pages, J.C.; Domenech, J.; Charbord, P. and Eder, V. (2005): Influence of hypoxia on the domiciliation of mesenchymal stem cells after infusion into rats: possibilities of targeting pulmonary artery remodeling via cell therapies? Respir Res, 27(6):125.

[37] Li, Y.; Chen, J.; Wang, L.; Lu, M.and Chopp, M. (2001): Treatment of stroke in rat with intracarotid administration of marrow stromal cells. Neurology 56(12): 1666-1672,

[38] Abdel Aziz, M.T.; Atta, H.M.; Mahfouz, S.; Fouad, H.H.; Roshdy, N.K.; Ahmed, H.H.; Rashed, L.A.; Sabry, D.; Hassouna, A.A. and Hasan, N.M. (2007): Therapeutic potential of bone marrow derived mesenchymal stem cells in experimental liver fibrosis. Clinical Biochem, 40(12): 893-899.

[39]Munoz-Fernandez, R.; Blanco, F.J.; Frecha, C.; Martin, F.; Kimatrai, M.; Abadia-Molina, A.C.; García-Pacheco, J.M. and Olivares, E.G. (2006): Follicular dendritic cells are related to bone marrow stromal cell progenitors and to myofibroblasts. J Immunol. 177(1):280-289

[40] Wu, D.C.; Boyed, A.S. And Wood, K.J. (2007): Embryonic stem cell transplantation; potential applicability in cell replacement therapy and regenerative medicine. Front Biosci, 12:4525-4535. 
[41] Roberts, D.W.; Bucci, T.J.; Benson, R.W.; Warbritton, A.R.; McRae, T.A.; Pumford, N.R. and Hinson, J.A. (1991): Immunohistochemical localization and quantification of the 3-(cysteine-S-yl)acetaminophen protein adduct in acetaminophen hepatotoxicity. Am J Pathol, 138(2): 359-371.

[42] Hu, B. and Colletti, L. M. (2008): Stem cell factor and c-kit are involved in hepatic recovery after acetaminopheninduced liver injury in mice. Am J Physiol Gastrointest, Liver Physiol, 295 (1): G45-G53

[43] Prescott, L.F. and Critchley, J.A. (1983): The treatment of acetaminophen poisoning. Annul Rev Pharmacol Toxicol, 23(1):87-101.

[44] Dixon, M.F.; Nimmo, J. and Prescott, L.F. (1971): Experimental paracetamol induced hepatic necrosis: a histopathological study. J Pathol, 103(4):225-229

[45] El-Khayat, Z.; Mostafa, E.; Hussein, J. I.; El-Waseef, M.; Rashed, L.; Farrag, A. R. and Medhat, D. (2013): Mesenchymal stem cells therapy for thioacetamide induced liver cirrhosis. Int J Pharm Sci, 5 (Supp1 2): 196-203

[46] Jang, Y.Y; Collector, M.I.; Baylin, S. B.; Diehl, A.M. and Sharkis, S.J. (2004): Hematopoietic stem cells convert into liver cells within days without fusion. Nat Cell Biol, 6(6): 532-539.

[47] Chang Liu, Z. and Chang, T.M. (2006): Coencapsulation of hepatocytes and bone marrow cells: In vitro and in vivo studies. Biotechnol Annu Rev, 12: 13751.

[48] Abd Aziz, M.T.; El Asmar, M.F.; Atta, H.M.; Mahfouz, S.; Fouad, H.H.; Roshdy, N.K.; Rashed, L.A.; Sabry, D.; Hassouna, A.A. and Taha, F.M. (2011): Efficacy of mesenchymal stem cells in suppression of Hepatocarcinorigenesis in rats; possible role of Wnt Signaling. J Exp Clin Cancer Res, 30: 49.

[49] Wang, Z. C.; Yang, S.; Huang, J. J.; Chen, S. L.; Li, Q. Q. and Li, Y. (2014):
Effect of Rougan Hauqian granules combined with human mesenchymal stem cells transplantation on liver fibrosis in cirrhosis rats. Asian Pac J Trop Med,7(7): 576-581.

[50] Luk, J.M.; Wang, P.P.; Lee, C.K.; Wang, T.H. and Fan, S.T. (2005): Hepatic potential of bone marrow stromal cells: Development of in bitro co-culture and intraportal transplantation models. J Immunol Methods, 305 (1): 39-49.

[51] Iredale, J.P.; Murphy, G.; Membry, R.M.; Friedman, S.L. and Arthur, M.J.P. (1992): Human hepatic lipocytes synthesize tissue inhibitory metallo proteinases-1 (TIMP1): Implications for regulation of matrix degeneration in liver. J Clin Invest, 90(1): 282-287.

[52] Alcolado, R.; Arthur, M.J.P. and Iredale, J.P. (1997): Pathogenesis of liver fibrosis. Clin. Sci, 92(2): 103-112.

[53] Arthur, M.J. (2000): Fibrogenesis II. Metalloproteinases and their inhibitors in liver fibrosis. Am J Physiol Gastrointest Liver Physiol, 279(2): G245-G 249.

[54]-Vetter, J. (1998): Toxins of Amanita phalloides. Toxicon, 36 (1): 13-24.

[55] Chandrasekaran, V. R. M.; Chien, S. P.; Hsu, D. Z.; Chang, Y. C. and Liu, M. Y. (2010): Effect of season on against after the onset of acetaminophen induced acute hepatic injury in rats. J Parenteral Int Nutr, 34 (5): 567-573.

[56] Ries, C.; Egea, V.; Karow, M.; Kolb, H.; Jochum, M. and Neth, P. (2007): MMP2MMP and TIMP -2 are essential for the invasive capacity of human mesenchymal stem cells, differential regulation by inflammatory cytokines. Blood, 109(9): 4055-4063.

[57] Stock, P.; Brückner, S.; Winkler, S.; Dollinger, M.M. and Christ, B. (2014): Human bone marrow mesenchymal stem cell-derived hepatocytes improve the mouse liver after acute acetaminophen intoxication by preventing progress of injury. Int J Mol Sci, 15 (4): 7004-7028. 


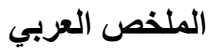

$$
\begin{aligned}
& \text { دراسات كيميائية حيوية جزيئية على الخلايا الجذعية للنخاع العظمي لمعالجة اضرار الكبد بالفئران }
\end{aligned}
$$

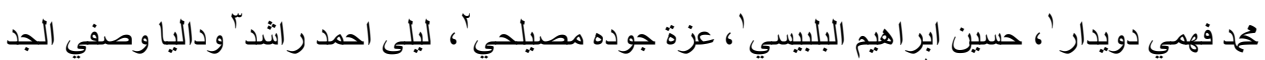

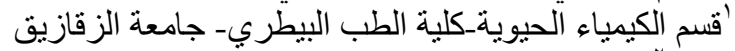

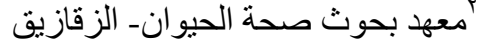

$$
\begin{aligned}
& \text { "َقسم الكيمياء الحيويةـ كلية الطب - جامعة القاهرة }
\end{aligned}
$$

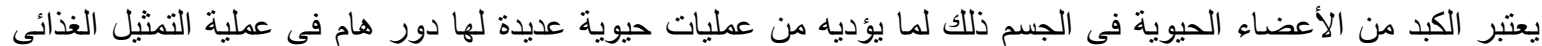

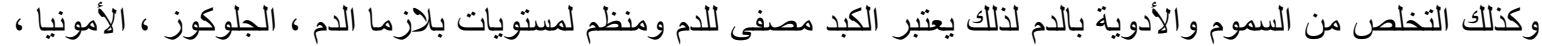

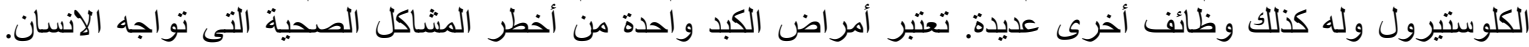

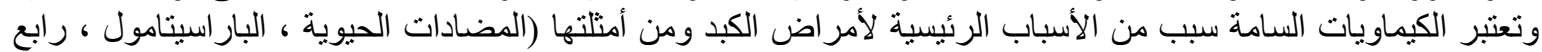

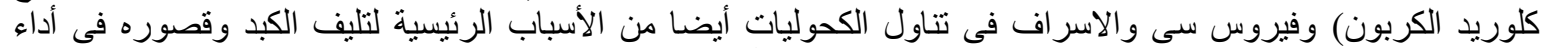

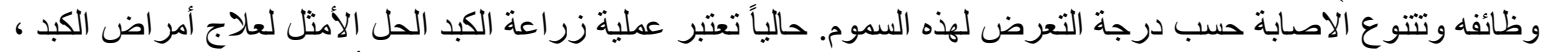

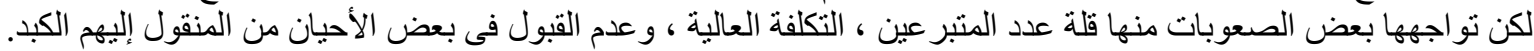

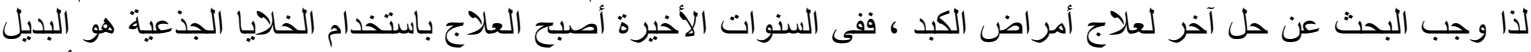

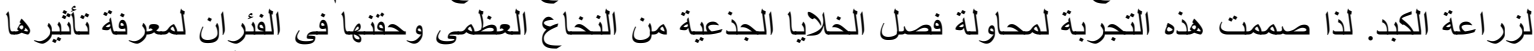

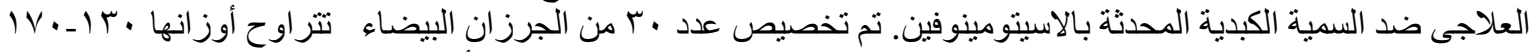

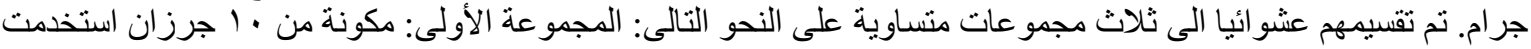

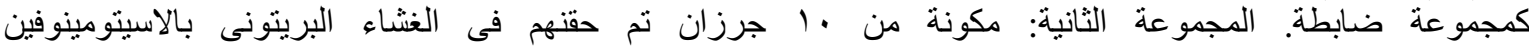

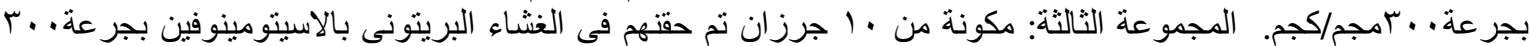

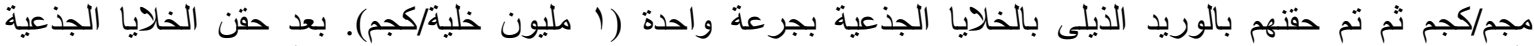

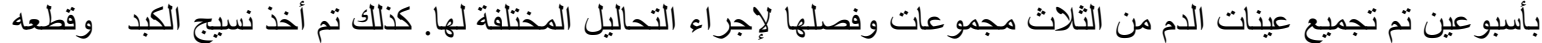

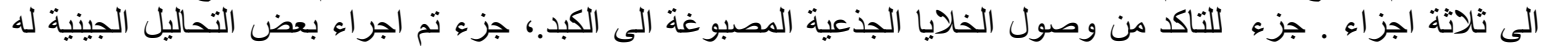

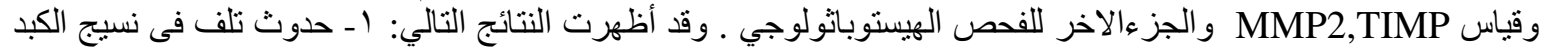

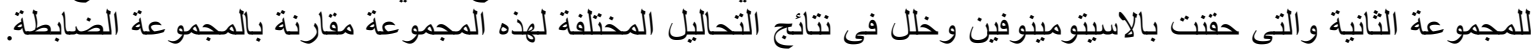

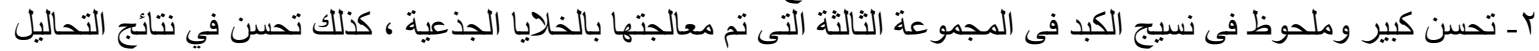

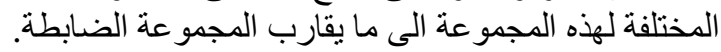

